\title{
DEVELOPMENT AND EVALUATION OF HERBAL ANTIAGING CREAM FORMULATION CONTAINING ANNONA SQUAMOSA LEAF EXTRACT
}

\author{
VANDANA MAHAWAR ${ }^{1}$, KALPANA PATIDAR ${ }^{2 *}$, NEELAM JOSHI ${ }^{1}$ \\ ${ }^{1}$ Department of Pharmaceutics, Master of Pharmacy, Mandsaur University, Mandsaur, Madhya Pradesh, India. ${ }^{2}$ Department of \\ Pharmaceutics, BR Nahata College of Pharmacy, Mandsaur, Madhya Pradesh, India. Email: kappharma@rediffmail.com
}

Received: 10 August 2018, Revised and Accepted: 16 October 2018

\section{ABSTRACT}

Objective: The objective of this research article is to develop and evaluate herbal anti-aging cream using Annona squamosa leaf extract due to its antioxidant potential.

Methods: Free radical scavenging activity of A. squamosa aqueous was determined by 2,2-diphenylpicrylhydrazyl (DPPH) method. 0.004\% ethanolic DPPH solution was prepared and from this solution $3 \mathrm{ml}$ was poured to each solution of the concentrated sample, after 30 min the absorbance of the anti-aging cream sample preparations was taken at $517 \mathrm{~nm}$ by a ultraviolet spectrophotometer and comparison is made between the absorbance of a sample and ascorbic acid (standard). The qualitative phytochemical analysis of A. squamosa (custard apple) leaf extract shows the presence of flavonoids, tannins, alkaloids, and phenols and absence of terpenoids and steroids

Results: Formulation $A_{3}$ shows good DPPH scavenging activity as compared to formulation $A_{1}$ and $A_{2}$ and ascorbic acid. Formulation $A_{3}$ is stable for 3 months.

Conclusion: Due to high antioxidant values of A. squamosa, it is concluded that it is possible to develop anti-aging cream using an aqueous extract of A. squamosa leaf.

Keywords: Skin aging, Free radicals, Antioxidants, Annona squamosa, 2,2-Diphenylpicrylhydrazyl assay.

(c) 2019 The Authors. Published by Innovare Academic Sciences Pvt Ltd. This is an open access article under the CC BY license (http://creativecommons. org/licenses/by/4. 0/) DOI: http://dx.doi.org/10.22159/ajpcr.2019.v12i2.29026

\section{INTRODUCTION}

Aged skin is a usual progression, and it is a consequence of the continual decaying process because to the harm of cellular DNA and protein [1]. Air, harsh sun rays, other environmental pollutants or other mechanical and chemical insults, induce the generation of free radicals (FR) as well as reactive oxygen species (ROS) of our own metabolism when human being exposed to it. Thus, skin aging is divided into these two categories: Natural or sequential and extraneous or photo-aging into common terms $[2,3]$.

A FR is any chemical species (atom, ion, or molecule) that contains an unpaired electron and in biological systems the common source of FR is oxygen [4]. FR are created as a consequence of ATP production by the mitochondria when cells use oxygen to generate energy, and they are generally called as ROS that result from the cellular redox process and play a dual role as both toxic and advantageous compounds [5].

FR are major causative factors in the induction of various skin diseases, including skin tumors, skin wrinkling, and skin aging. Ultraviolet (UV) mainly produces FR/ROS through interaction with endogenous photo sensitizers which leads together to cumulative structural and physiological alterations and progressive changes in each skin layer as well as changes in skin appearance $[6,7]$.

Antioxidative defense mechanisms are the most effective path to eliminate and diminish the action of FR which cause oxidative stress [8]. They are natural scavengers of FR, known to cause cellular damage and consequent age-related medical disorders (including wrinkling of skin) [9]. Topical application of antioxidants may be beneficial for protecting the skin against environmental factors. Antioxidant compounds play an important key ingredient in skin caring products such as creams and lotions which have received importance in the present scenario $[10,11]$. Antioxidants such as Vitamin E and C, carotenoids, flavonoids, and tannins are present in various plants insubstantial amount and can be utilized to scavenge the overindulgence FR from the human body. Custard apple plant is one of them which contains potent antioxidants [12].

Annona squamosa, one of the important medicinal plants, commonly called "custard apple," belonging to the family Annonaceae. It possesses a wide variety of pharmacological activities and is used in traditional applications [13]. Flavonoids are natural products, which have been shown to possess various biological properties related to the antioxidant mechanism and leaves of $A$. squamosa are rich in flavonoids such as rutin and hyperoside [14]. Presence of acetogenins, polyphenols in leaves of $A$. squamosa probably play a role as an effective FR scavenger [15]. A. squamosa extract increases cellular proliferation and increases collagen [16]. Since custard apple has tremendous antioxidants, it is good if custard apple is being developed as pharmaceutical products, especially as cosmetics. Thus, the current research study focused to protect the skin against oxidative damage and eliminate the FR.

\section{METHODS}

Leaves of custard apple (A. squamosa Linn.) were collected from local regions near Ratlam city (M.P.). The leaves were authenticated by Dr. S.N. Mishra (head AINP on M and AP) KNK college of Horticulture, Mandsaur (M.P.). Chemicals were collected from the storehouse of college.

Extraction of $A$. squamosa (custard apple) leaves by means of distilled water

Leaves of $A$. squamosa were shade dried at room temperature for 4-5 days. The dried leaves were crushed to coarse powder. A. squamosa leaves extract was prepared by boiling $30 \mathrm{~g}$ leaves of $A$. squamosa in $800 \mathrm{ml}$ of water for $2 \mathrm{~h}$ and then filtered by muslin cloth. Then, the 
liquid obtained was poured into a China dish and heated gently over the water bath. When the liquid gets evaporated to cool the content and scratches it, the dark brown extract was obtained. The extract stored in a refrigerator at $2-8^{\circ} \mathrm{C}$ for subsequent experiments (Fig. 1) $[17,18]$.

\section{Phytochemical screening of leaf extract of $A$. squamosa (custard} apple)

Phytochemical screening of the freshly prepared crude extract was qualitatively tested for the presence of chemical constituents, and it was performed using the following reagents and chemicals [19].

\section{Test for flavonoids}

A few drops of dilute sodium hydroxide were added to $1 \mathrm{ml}$ of the extract. An intense yellow color was produced in plant extract, which becomes colorless in an addition of a few drops of dilute acid indicates the presence of flavonoids [20].

\section{Test for terpenoids}

Chloroform (2 ml) and concentrated $\mathrm{H}_{2} \mathrm{SO}_{4}$ were added with plant extract to form a layer. The presence of terpenoids is determined when a reddish-brown coloration at the interface was formed [21]

\section{Test for tannins and phenols}

The test extract was taken in water, warmed and filtered. $5 \mathrm{~mL}$ of the filtrate were allowed to react with $1 \mathrm{~mL}$ of $5 \%$ ferric chloride solution. Dark green or deep blue color shows the presence of tannins and phenols [22].

\section{Test for the steroid}

From $0.5 \mathrm{ml}$ of acetic anhydride to $0.5 \mathrm{ml}$ of chloroform, the extract was treated and then concentrated solution of sulfuric acid was added slowly, and the green-bluish color was produced which shows the presence of steroids [23].

\section{Test for alkaloids}

About $1 \mathrm{ml}$ of extract adds to $2 \mathrm{ml}$ of Wagner's reagent (iodine in potassium iodide) a reddish brown precipitate confirms the presence of alkaloids [24].

\section{A procedure of anti-aging cream}

An anti-aging cream contains an aqueous phase and oil phase. Oil phase like (stearic acid an emulsifier and other oil miscible components olive oil, and cetyl alcohol) was mixed (Part A) and heated up to $75^{\circ} \mathrm{C}$. Components of aqueous phase (Part B) mixed together and warmed to about the same temperature of an oil phase. After heating, the aqueous phase and oil phase were mixed by continuous stirring in a magnetic stir. The therapeutically active ingredient and preservative sodium benzoate were added after cooling to $40^{\circ} \mathrm{C}$. Perfume was added (Table 1 and Fig. 2) [25,26].

\section{Determination of antioxidant activity}

The FR scavenging activity of the H-donor ability was assessed using an ethanol solution of 2,2-diphenylpicrylhydrazyl (DPPH), a stable nitrogen-centered FR. FR scavenging activity of an anti-aging cream formulation was determined by DPPH which acts as a stable FR.

\section{Sample preparation}

About $10 \mathrm{mg}$ cream formulations were weight and dissolve in ethanol. Prepared sample was filtered by the Whatman filter paper, and volume makes up to $10 \mathrm{ml}$ in a volumetric flask.

\section{Preparation of standard}

Accurately weighed $10 \mathrm{mg}$ of ascorbic acid and dissolved in $10 \mathrm{ml}$ of ethanol. From this solution, take $2.5 \mathrm{ml}$ and volume make up to $25 \mathrm{ml}$ with ethanol thus the stock solution is prepared. This stock solution was serially diluted separately to obtain different concentrations.

\section{Procedure}

Up to $3 \mathrm{ml}$ of $0.004 \%$, ethanolic DPPH solution was added with the $0.5 \mathrm{ml}$ sample solution. At $517 \mathrm{~nm}$ DPPH shows its absorbency and at the same wavelength sample absorbance was taken by a UV spectrophotometer after $30 \mathrm{~min}$ and then comparison was made between the absorbance of a sample and the absorbance of ascorbic acid (standard) Then, the percentage inhibition was calculated by the following equation $[27,28]$.

$$
\% \text { Inhibition }=\frac{(\text { Absorbance of the sample })}{(\text { Absorbance of control })} \times 100
$$

\section{Evaluation parameters of anti-aging herbal cream Organoleptic properties}

The organoleptic test of a cream preparation was performed visually including color, odor, and clarity [29].

\section{Stability of a formulation}

Stability of a formulation was evaluated by placing formulation at different storage conditions, that is, 8,25 , and $40^{\circ} \mathrm{C}$ for 3 months [30].

\section{Homogeneity}

The prepared cream formulation was evaluated by visual appearance for its homogeneity.

\section{After feel}

The quantity of cream formulation left after the application and slipperiness and emolliency was also reported [31].

\section{Washability}

To determine the washability of a formulation a small amount of cream applied to the skin and wash under tap water with minimal force to remove the cream [32].

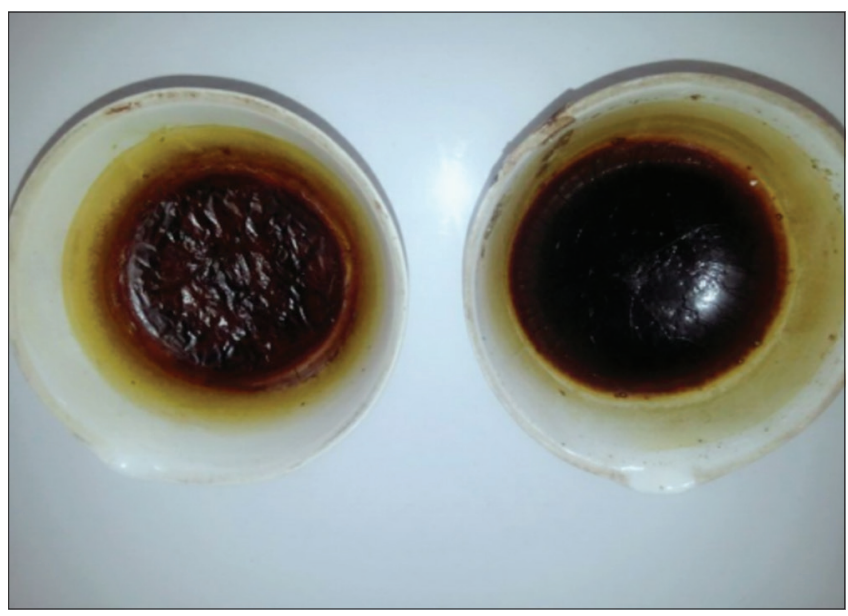

Fig. 1: Herbal extract of custard apple

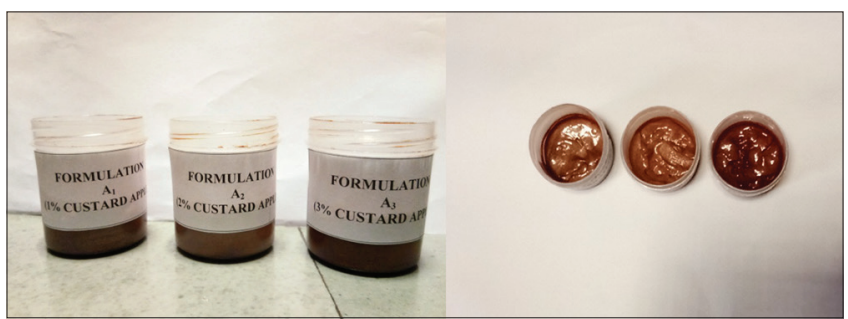

Fig. 2: Formulated anti-aging cream containing custard apple leaf extract 
Table 1: Composition of herbal anti-aging cream formulation containing Annona squamosa (custard apple) extract

\begin{tabular}{|c|c|c|c|c|c|}
\hline Ingredient & $A_{1}$ & $\mathrm{~A}_{2}$ & $\mathrm{~A}_{3}$ & $\mathrm{~A}_{4}$ & $A_{5}$ \\
\hline Annona squamosal (g) & 1 & 2 & 3 & 4 & 5 \\
\hline Stearic acid (g) & 6.2 & 6.2 & 6.2 & 6.2 & 6.2 \\
\hline Cetyl alcohol (g) & 0.75 & 0.75 & 0.75 & 0.75 & 0.75 \\
\hline Olive oil (ml) & 1 & 1 & 1 & 1 & 1 \\
\hline Polyethylene glycols (ml) & 1.5 & 1.5 & 1.5 & 1.5 & 1.5 \\
\hline Glycerine $(\mathrm{ml})$ & 2 & 2 & 2 & 2 & 2 \\
\hline Triethanolamine (ml) & 0.5 & 0.5 & 0.5 & 0.5 & 0.5 \\
\hline Sodium benzoate (g) & 0.25 & 0.25 & 0.25 & 0.25 & 0.25 \\
\hline Ethylene diamine tetra acetic acid (g) & 0.020 & 0.020 & 0.020 & 0.020 & 0.020 \\
\hline Rose water (ml) & 3 & 3 & 3 & 3 & 3 \\
\hline Water & Q.S. & Q.S. & Q.S. & Q.S. & Q.S. \\
\hline
\end{tabular}

Table 2: Qualitative phytochemical analysis of Annona squamosa (custard apple)

\begin{tabular}{lll}
\hline S. No. & Phytochemicals & Custard apple (aqueous extract) \\
\hline 1 & Flavonoids & + \\
2 & Terpenoids & - \\
3 & Tannin & + \\
4 & Phenols & + \\
5 & Steroids & - \\
6 & Alkaloids & + \\
\hline
\end{tabular}

Table 3: Physical Properties of herbal anti-aging cream formulations

\begin{tabular}{lll}
\hline S. No. & Properties & $\mathbf{A}_{\mathbf{3}}$ (Custard apple extract) \\
\hline 1. & Color & Brown in color \\
2. & Odor & Characteristic \\
3. & State & Semi-solid \\
4. & Texture & Smooth \\
5. & Grittiness & No grittiness \\
\hline
\end{tabular}

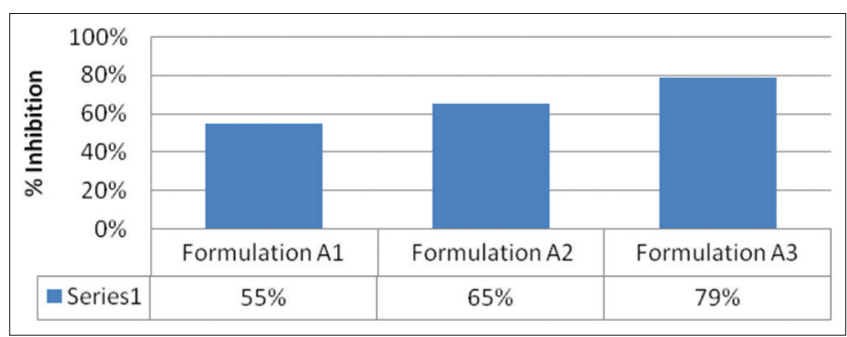

Fig. 3: 2,2-Diphenylpicrylhydrazyl scavenging activity of anti-aging cream formulations

Type of smear

After applying the cream formulation to the skin a film or smear formed which was determined [33].

\section{pH of the cream}

To determine $\mathrm{pH}$ of anti-aging cream formulation a $\mathrm{pH}$ meter is used. Put $50.0 \mathrm{ml}$ water in a beaker and dissolved the weighed amount of cream ( $5 \mathrm{~g}$ ) in it and its $\mathrm{pH}$ was measured [34]. The $\mathrm{pH}$ study of a cream formulation was determined in triplicate, and the average of three reading is recorded [35].

\section{Irritancy test}

The cream was applied on the skin, and time was noted. Irritancy, erythema, was checked after application of cream formulation on a specified area of skin and reported at regular intervals up to $24 \mathrm{~h}[36]$.

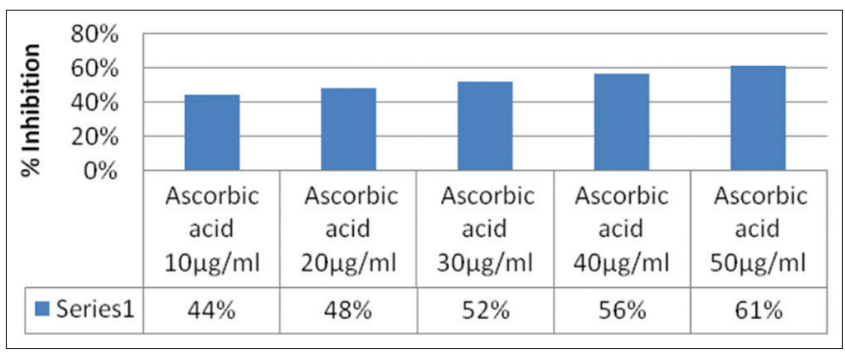

Fig. 4: 2,2-Diphenylpicrylhydrazyl scavenging activity of ascorbic acid (standard)

\section{RESULTS AND DISCUSSION}

Phytochemical screening of leaf extract of $A$. squamosa (custard apple)

The qualitative phytochemical analysis of A. squamosa (custard apple) leaf extract shows the presence of flavonoids, tannins, alkaloids, and phenols and absence of terpenoids and steroids as shown in Table 2.

\section{DPPH radical scavenging activity}

The antioxidant activity of A. squamosa (custard apple) cream formulation was assessed using DPPH radical scavenging activity and by taking ascorbic acid as standard. Formulation $\mathrm{A}_{3}$ (custard apple) shows maximum percentage inhibition of DPPH of about $78 \%$, as compared to ascorbic acid which shows maximum $61 \%$ inhibition ( $50 \mu \mathrm{g} / \mathrm{ml}$ ) of DPPH. Fig. 3 shows DPPH scavenging activities of formulation $A_{1}, A_{2}$, and $A_{3}$ containing custard apple extract in different concentrations and Fig. 4 shows DPPH scavenging activities of ascorbic acid at different concentrations.

\section{Evaluation parameter of herbal anti-aging cream formulations} Physical properties

Physical properties of formulation $\mathrm{A}_{3}$ are shown in Table 3 .

\section{Stability studies}

Table 4 depicts that all the physicochemical parameters were well maintained during the period of accelerated stability studies at temperatures $8^{\circ} \mathrm{C}$ in the refrigerator and at $25^{\circ} \mathrm{C}, 40^{\circ} \mathrm{C}$ in an incubator for 3 months. Formulation $\mathrm{A}_{3}$ containing custard apple extract shows good stability in color, odor, and consistency until the end of the accelerated study. Moreover, Table 5 represents the $\mathrm{pH}$ study of a cream formulation at different temperature for 3 months.

\section{CONCLUSION}

Due to constant exposure of human skin to the UV radiations present in sunlight, several pathobiological alterations in cells occur such as irregular pigmentation, increased wrinkling, loss of elasticity, dryness, and roughness. For the protection of this signs of aging herbal cosmetic are used as a therapy. Various active constituents such as flavonoids and phenolic acids appear efficient against UV radiation-induced damage. 
Table 4: Accelerated Stability Studies of formulation $\mathrm{A}_{3}$

\begin{tabular}{|c|c|c|c|c|c|c|c|c|}
\hline \multicolumn{9}{|c|}{ Formulation $\mathrm{A}_{3}$} \\
\hline $\begin{array}{l}\text { Time } \\
\text { duration }\end{array}$ & $\begin{array}{l}\text { Temp } \\
\text { erature }\left({ }^{\circ} \mathrm{C}\right)\end{array}$ & Appear ance & Homogeneity & Spreadability & After feel & $\begin{array}{l}\text { Type of } \\
\text { smear }\end{array}$ & Removal & Irritation \\
\hline \multirow[t]{3}{*}{ Initial month } & $4-8$ & No changein color & Good & Good & Emollient and slipperiness & Non-greasy & Easy & Nil \\
\hline & 25 & No changein color & Good & Good & Emollient and slipperiness & Non-greasy & Easy & Nil \\
\hline & 40 & No changein color & Good & Good & Emollient and slipperiness & Non-greasy & Easy & Nil \\
\hline After & $4-8$ & No changein color & Good & Good & Emollient and slipperiness & Non-greasy & Easy & Nil \\
\hline \multirow[t]{2}{*}{1 month } & 25 & No changein color & Good & Good & Emollient and slipperiness & Non-greasy & Easy & Nil \\
\hline & 40 & No changein color & Good & Good & Emollient and slipperiness & Non-greasy & Easy & Nil \\
\hline After & $4-8$ & No changein color & Good & Good & Emollient and slipperiness & Non-greasy & Easy & Nil \\
\hline \multirow[t]{2}{*}{2 months } & 25 & No changein color & Good & Good & Emollient and slipperiness & Non-greasy & Easy & Nil \\
\hline & 40 & No changein color & Good & Good & Emollient and slipperiness & Non-greasy & Easy & Nil \\
\hline After & $4-8$ & No changein color & Good & Good & Emollient and slipperiness & Non-greasy & Easy & Nil \\
\hline \multirow[t]{2}{*}{3 months } & 25 & No changein color & Good & Good & Emollient and slipperiness & Non-greasy & Easy & Nil \\
\hline & 40 & No changein color & Good & Good & Emollient and slipperiness & Non-greasy & Easy & Nil \\
\hline
\end{tabular}

Table 5: pH study of formulation $A_{3}$

\begin{tabular}{llll}
\hline Formulation & Time duration & Temperature $\left({ }^{\circ} \mathbf{C}\right)$ & $\mathbf{p H}$ \\
\hline $\mathrm{A}_{3}$ & Initial month & $4-8$ & $5.4 \pm 0.25$ \\
& & 25 & $5.6 \pm 0.40$ \\
& & 40 & $5.3 \pm 0.23$ \\
& After & $4-8$ & $5.7 \pm 0.36$ \\
& 1 month & 25 & $5.1 \pm 0.20$ \\
& 40 & $5.6 \pm 0.44$ \\
& After & $4-8$ & $5.1 \pm 0.30$ \\
& 2 months & 25 & $5.8 \pm 0.30$ \\
& After & 40 & $5.0 \pm 0.20$ \\
& 3 months & 25 & $4.8 \pm 0.24$ \\
& 40 & $5.6 \pm 0.36$ \\
& & & $5.4 \pm 0.26$ \\
\hline
\end{tabular}

The use of natural compounds in skin protection especially topical application of antioxidants indicates their popularity in decreasing the effect of aging on the skin. Thus, the aim of this research article is to develop and evaluate herbal anti-aging cream containing $A$. squamosa extract. A. squamosa leaves are rich in antioxidants, and they thicken and stimulate the collagen to reduce wrinkles and fine lines, improving the elasticity of the skin and providing a healthy skin. Antioxidants fight the harsh rays of the sun, protecting from sun damage.

The present research study revealed that the custard apple leaves were having higher radical scavenging activity compared to that of ascorbic acid which was taken as standard. The evaluation test reveals that the formulated anti-aging cream from custard apple leaves extract showed that it is safe to be used in the skin to protect from intrinsic and extrinsic aging.

Moreover, our research study presented that formulation of $\mathrm{A}_{3}$ is stable for 3 months. The formulations $\mathrm{A}_{3}$ were homogeneous, emollient, non-greasy, and easily removed after the application and showed good spreadability, no evidence of phase separation and good consistency during the study period. Formulation $\mathrm{A}_{3}$ shows the proper $\mathrm{pH}$ range which confirms the compatibility of the formulation with skin secretions. From this study, it is concluded that it is possible to develop anti-aging cream containing custard apple leaf extract and it will help in reducing oxidative damage and give the antioxidant effect to our skin due to its high antioxidant values.

\section{ACKNOWLEDGMENTS}

The authors would like to thank Dr. Kalpana Patidar, Head, Department of Pharmaceutics, B.R. Nahata College of Pharmacy, Mandsaur, Madhya Pradesh, and Ms. Neelam Joshi, Research Scholar, Mandsaur University, Mandsaur, Madhya Pradesh, for supporting us for the completion of this research work.

\section{AUTHORS' CONTRIBUTION}

All the authors have equally contributed.

\section{CONFLICTS OF INTEREST}

The authors declare that there are no conflicts of interest.

\section{REFERENCES}

1. Gavarkar P, Thorat S, Adnaik R, Mohite S, Magdum C. Characterization and formulation of skin cream from seed oil extracted from Cucumis Melo. Pharm Lett 2016;8:90-3.

2. Poljsak B, Glavan U, Dahmane R. Skin cancer, free radicals and antioxidants. Int J Cancer Res Prev 2011;4:193-217.

3. Ortolan MC, Simoes ML, Baroni ER, Auersvald A, Auersvald LA, Rodrigues $\mathrm{M}$, et al. Influence of aging on the skin quality of whiteskinned women: The role of collagen, elastic material density, and vascularisation. Rev Bras Cir Plást 2013;28:41-8.

4. Wickens AP. Ageing and the free radical theory. Respir Physiol 2001;128:379-91.

5. Kabel AM. Free radicals and antioxidants: Role of enzymes and nutrition. World J Nutri Health 2014;2:35-8.

6. Herrling T, Jung K, Fuchs J. The important role of melanin as protector against free radicals in skin. SOFW J Cosmet 2007;9:26-32.

7. Ganceviciene R, Liakou AI, Theodoridis A, Makrantonaki E, Zouboulis CC. Skin anti-aging strategies. Dermatoendocrinol 2012;4:308-19.

8. Veeru P, Mishra PK, Mishra M. Screening of medicinal plant extracts for antioxidant activity. J Med Plant Res 2009;3:608-12

9. Uwa LM. The anti-aging efficacy of antioxidants. Curr Trends Biomed Eng Biosci 2017;7:1-3.

10. Khare N, Khare PP, Yadav G. Recent advances in anti-aging-a review. Global J Pharmacol 2015;9:267-71.

11. Makarova K, Zawada K, Wagner D, Skowyra J. Optimization of antioxidant properties of creams with berry extracts by artificial neural networks. Acta Phys Pol 2017;132:44-51.

12. Dua D, Srivastava NS. A study on antioxidant and anti-aging properties of few medicinal plants. Int J Pharm Pharm Sci 2015;8:344-7.

13. Kalidindi N, Thimmaiah NV, Jagadeesh NV, Nandeep R, Swetha S, Kalidindi B, et al. Antifungal and antioxidant activities of organic and aqueous extracts of Annona squamosa Linn. Leaves. J Food Drug Anal 2015;23:795-802.

14. Shirwaikar A, Rajendran K, Kumar CD. In vitro antioxidant studies of Annona squamosa Linn. Leaves. Indian J Exp Biol 2004;42:803-7.

15. Surendra G, Male A, Ratala RN. DPPH Free radical scavenging activity of Annona squamosa Linn leaf extracts. Int J Pharm Biol Sci 2016;11:4-6.

16. Krishnan RD, Kumar MV, Varma RS, Babu UV, Dhanabal SP. Design and development of polyherbal based cream formulation with anti-skin ageing benefits. Int J Pharm Sci Res 2017;8:4147-58.

17. Kaleem M, Asif M, Ahmed QU, Bano B. Antidiabetic and antioxidant activity of Annona squamosa extract in streptozotocin-induced diabetic rats. Singapore Med J 2006;47:670-5.

18. Gupta RK, Kesari AN, Watal G, Murthy PS, Chandra R, Maithal K, et al. Hypoglycaemic and antidiabetic effect of aqueous extract of leaves of Annona squamosa (L.)in experimental animal. Curr Sci 2005;88:1244-54.

19. Rahman MH, Alam MB, Hossain MS, Jha MK, Islam A. Antioxidant, analgesic and toxic potentiality of methanolic extract of Stephania japonica (thunb.) Miers. Leaf. Asian J Pharm Clin Res 2011;4:38-41.

20. Mhatre J, Nagaral S, Kulkarni S. Formulation and evaluation of 
antibacterial activity of a herbal ointment prepared from crude extracts of Aegle marmelos, (bael). Int J Pharm Pharm Sci 2014;6:575-9.

21. Sivaraj R, Balakrishnan A, Thenmozhi M, Venckatesh R. Preliminary phytochemical analysis of Aegle marmelos, Ruta graveolens, Opuntia dellini, Euphorbia royleana and Euphorbia antiquorum. Int J Pharm Sci Res 2011;2:132-6.

22. Khatri P, Rana JS, Jamdagni P, Sindhu A. Phytochemical screening, GC-Ms and FT-IR analysis of methanolic extract leaves of Elettaria cardamomum. Int J Res Granthaalayah 2017;5:213-24.

23. Tariq AL, Reyaz. AL. Phytochemical analysis of Camellia sinensis Leaves. Int J Drug Dev Res 2012;4:311-6.

24. Inamdar P, Desai S, Patel D, Meshram D. Phytochemical screening and in vitro antifungal activity of Camellia sinensis. Int J Pharm Pharm Sci 2014;6:148-50.

25. Rao PK, Khaliq K, Kharat SS, Sagare P, Patil SK. Preparation and evaluation o/w cream for skin psoriasis. Int J Pharm Bio Sci 2010;1:1-11.

26. Mishra AP, Saklani S, Milella L, Tiwari P. Formulation and evaluation of herbal antioxidant face cream of Nardostachys jatamansi collected from Indian Himalayan region. Asian Pac J Trop Biomed 2014;4:S679-82.

27. Ali A, Akhtar N, Khan HM. Assessment of physical stability and antioxidant activity of polysiloxane polyalkyl polyether copolymerbased creams. J Chem 2013;1:1-7.

28. Naithani V, Singhal AK, Bangar OP, Chaudhary M. Comparative evaluation of antioxidant activity of acnano and it's comparison with two commercial anti-acne drugs. J Pharm Res 2011;4:4646-9.

29. Maha HL, Sinaga KR. Formulation and evaluation of miconazole nitrate nanoemulsion and cream. Asian J Pharm Clin Res 2018;11:319-21.

30. Akhtar N, Khan BA, Haji M, Khan S, Ahmad M, Rasool F, et al. Evaluation of various functional skin parameters using a topical cream of Calendula officinalis extract. Afr J Pharm Pharmacol 2011;5:199-206.

31. Mangilal T, Patnaik KS, Sunder RS, Bai SA. Preparation and evaluation of poly herbal anti-aging cream by using different synthetic polymers. Int J Herb Med 2017;5:92-5.

32. Kumara DK, Satyanarayana T, Kumar CH, Moulabi SK, Pullarao B, Gavamma A, et al. Formulation and evaluation of herbal vanishing cream containing Punica granatum. Indo Am J Pharm Res 2016;6:4938-44.

33. Himaja N. Formulation and evaluation of herbal cream from Azadirachta indica ethanolic extract. Int J Res Drug Pharm Sci 2017;1:23-4.

34. Gupta N, Dubey A, Prasad P, Roy A. Formulation and evaluation of herbal fairness cream comprising hydroalcoholic extracts of Pleurotus ostreatus, Glycyrrhiza glabra and Camellia sinensis. U K J Pharm Biosci 2015;3:40-5.

35. Kumar KK, Sasikanth K, Sabareesh M, Dorababu N. Formulation and evaluation of diacerein cream. Asian J Pharm Clin Res 2011;4:93-8.

36. Singh M, Sharma S, Khokra SL, Sahu RK, Jangde R. Preparation and evaluation of herbal cosmetic cream. Pharmacologyonline 2011;2:1258-64. 